\title{
Periocular Cutaneous Mucormycosis Caused by Saksenaea erythrospora
}

\author{
Bunyada Putthirangsiwong ${ }^{1}$ Pornchai Mahaisavariya ${ }^{1}$ Weerawan Chokthaweesak ${ }^{1}$ Dinesh Selva ${ }^{2}$ \\ ${ }^{1}$ Department of Ophthalmology, Ramathibodi Hospital, Mahidol \\ University, Bangkok, Thailand \\ ${ }^{2}$ Department of Ophthalmology \& Visual Sciences, University of \\ Adelaide and South Australian Institute of Ophthalmology, \\ Adelaide, Australia \\ Address for correspondence Bunyada Putthirangsiwong, MD, \\ Department of Ophthalmology, Faculty of Medicine Ramathibodi \\ Hospital, Mahidol University, 270 Rama VI Rd., Ratchathewi, Bangkok \\ 10400, Thailand (e-mail: bunyada63@gmail.com).
}

J Pediatr Infect Dis 2019;14:209-212.

\section{Introduction}

Saksenaea spp. is a monotypic genus in the order Mucorales capable of causing human mucormycosis infection. ${ }^{1}$ There are three described species; Saksenaea vasiformis, Saksenaea oblongispora, and Saksenaea erythrospora. ${ }^{2}$

S. erythrospora is a new species, which has been recently reported to produce severe human infection. Most clinical manifestations are cutaneous and subcutaneous infection. In a review of the literature, there were 10 adult cases of human infection caused by $S$. erythrospora reported worldwide. ${ }^{3-8}$ We describe a case of pediatric primary cutaneous infection caused by $S$. erythrospora with subcutaneous spread involving the nasolacrimal, cheek, and nasal regions in an immunocompetent host.

\section{Case Report}

A 16-month-old boy was referred with a 3-week history of a progressive painful mass at the right medial canthus and upper

received

July 4, 2017

accepted after revision

October 18, 2017

published online

December 6, 2017

cheek. One week earlier, the patient had been admitted with a diagnosis of dacryocystitis at a rural hospital. He was given intravenous Augmentin $40 \mathrm{mg} / \mathrm{kg} /$ day and clindamycin $25 \mathrm{mg} /$ $\mathrm{kg} /$ day. The mass continued to increase in size despite treatment and he developed restriction in downward gaze. Past medical history was unremarkable and there was no significant history of prior trauma except suspected occult skin trauma on his face while playing at a playground.

The patient was afebrile and appeared systemically well. On ophthalmic exam, the right eye revealed a normal visual acuity by preferential looking test. He had a hard 3 by $1 \mathrm{~cm}$ subcutaneous mass at right medial canthal region extending to the nose and cheek (-Fig. 1A). Down gaze was slightly limited with upward displacement of the right globe. There was no proptosis and the remainder of the ocular examination was unremarkable. His blood investigations for complete blood count and anti-HIV were within normal limit.

Magnetic resonance imaging (MRI) showed an enhancing infiltrative lesion involving the right nasolacrimal region,

Copyright @ 2019 by Georg Thieme Verlag KG, Stuttgart · New York
DOI https://doi.org/ 10.1055/s-0037-1608888. ISSN 1305-7707. 


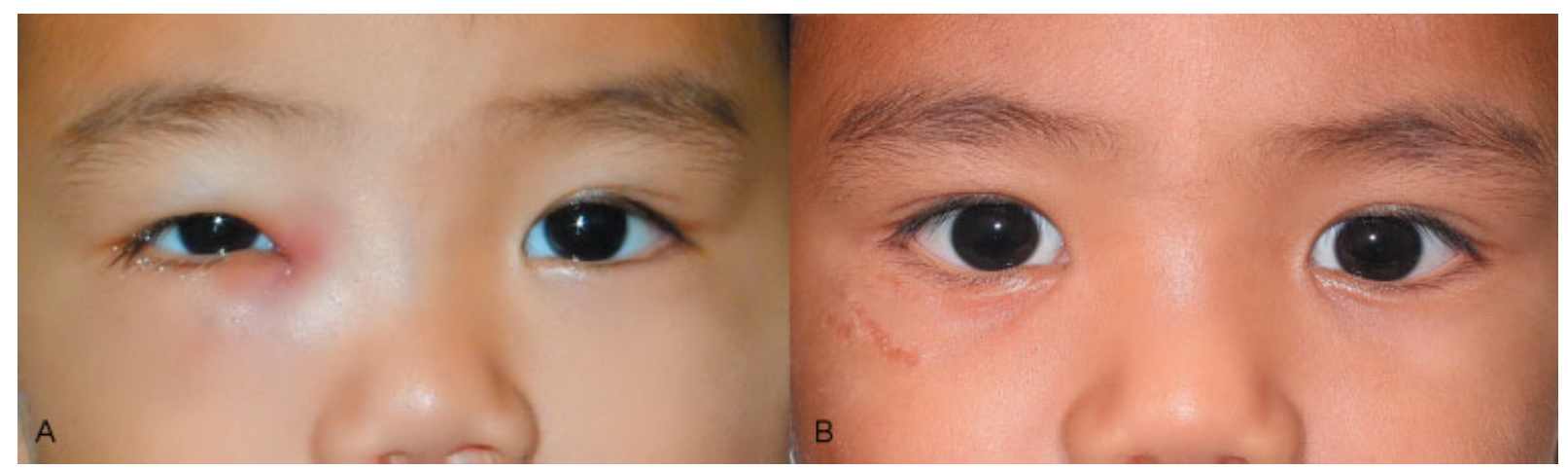

Fig.1 (A) Photograph of the patient before treatment demonstrating subcutaneous mass at right medial canthal region extending to nose and cheek with eyelid edema and redness. (B) Four months after treatment with clinical improvement.

extraconal medial and inferior aspects of the right orbit, and the subcutaneous soft tissue of the right cheek and nose without sinus involvement (-Fig. 2A).

An anterior orbitotomy was performed via a subciliary incision with incisional biopsy. Intraoperative irrigation of the ipsilateral nasolacrimal system demonstrated patency without reflux, effectively ruling out the original presumptive diagnosis of dacryocystitis. Pale, firm nonviable tissue was found and sent for culture and pathological examination. Culture demonstrated broad nonseptate sterile hyphae. A piece of the Sabouraud dextrose agar with fluffy, white mycelial growth was then placed in yeast extract. After 1 week of incubation, long sporangiophores, flask-shaped sporangia were identified suggestive of Saksenaea spp. DNA extraction, amplification, and sequencing analysis identified S. erythrospora.

The patient was initially treated with $1.5 \mathrm{mg} / \mathrm{kg} / \mathrm{day}$ of intravenous conventional amphotericin $B$ and changed to $5 \mathrm{mg} / \mathrm{kg} /$ day of liposomal amphotericin B after 1 week due to rising serum creatinine. He also underwent additional surgical debridement. After 4 weeks of treatment, he was discharged and continued treatment with itraconazole oral suspension $10 \mathrm{mg} / \mathrm{kg} /$ day. At 1 month follow-up, he developed recurrent right lower eyelid swelling and redness. He was readmitted and repeat MRI showed a residual enhancing lesion with no significant change compared with the radiographic appearance prior to treatment. He had a further surgical debridement and was again treated with intravenous liposomal amphotericin B for 33 days and followed by itraconazole oral suspension $13 \mathrm{mg} / \mathrm{kg} /$ day for further 2 weeks. At last follow-up, 4 months later, he showed complete clinical and radiographic resolution (-Figs. 1B and 2B).

\section{Discussion}

The genus Saksenaea was first reported by Saksena in $1953^{9}$ from forest soil in India. After the discovery of new species in Saksenaea spp. by Alvarez et al in 2010, there were three species overall within this genus. Saksenaea vasiformis was the first species in this genus reported to cause human infection in $1976^{10}$ and since then, approximately 40 cases have been published in the English-language literature. ${ }^{11}$ Saksenaea oblongispora has not been reported to cause human infection.

Saksenaea erythrospora is increasingly being described as a cause of human infection. Up to now, there are 10 cases of S. erythrospora infection reported ( - Table 1 ).$^{3-8}$ However, it
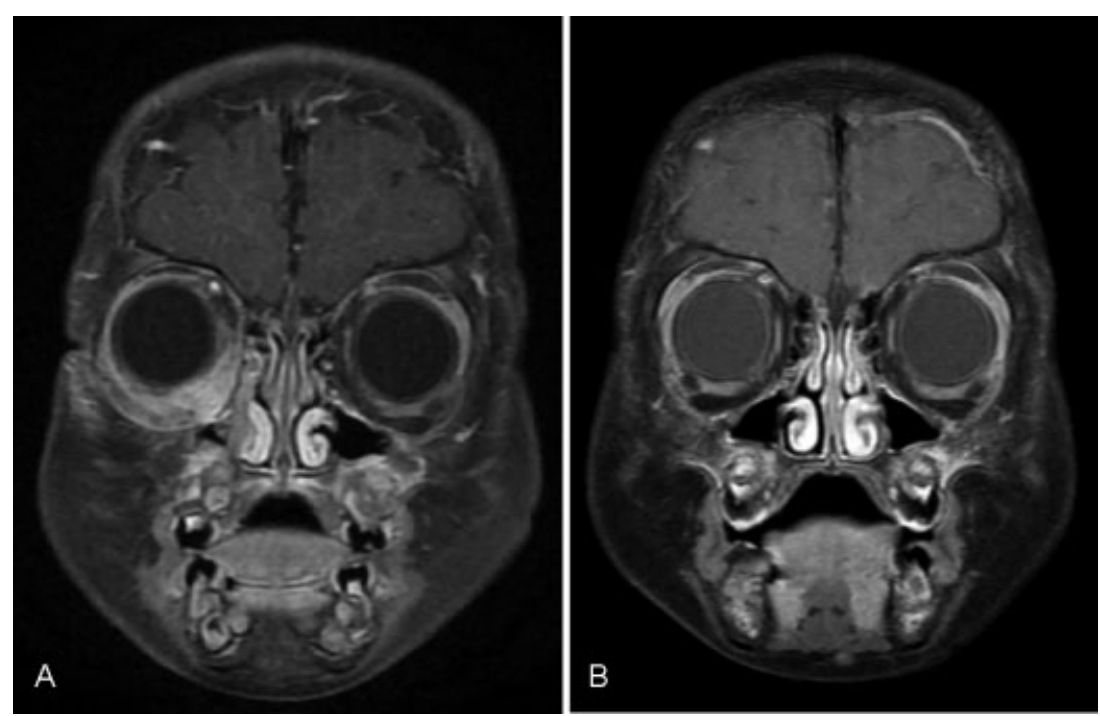

Fig. 2 (A) Coronal T1-weighted magnetic resonance imaging (MRI) before treatment shows enhancing infiltrative lesion involving the right nasolacrimal region and right orbit. (B) At 4 months of follow-up, MRI reveals complete resolution of the preexisting lesion. 
Table 1 Published cases of Saksenaea erythrospora infection

\begin{tabular}{|c|c|c|c|c|c|}
\hline Reference & Sex/age (y) & $\begin{array}{l}\text { Cause of } \\
\text { infection }\end{array}$ & $\begin{array}{l}\text { Clinical } \\
\text { manifestation }\end{array}$ & Immune status & $\begin{array}{l}\text { Result of } \\
\text { treatment }\end{array}$ \\
\hline Hospenthal et $\mathrm{al}^{3}$ & $\operatorname{Man} / 26$ & Combat trauma & $\begin{array}{l}\text { Cutaneous and } \\
\text { subcutaneous } \\
\text { mucormycosis }\end{array}$ & Immunocompetent & Death \\
\hline Chantharit et al ${ }^{4}$ & Man/56 & Unknown & $\begin{array}{l}\text { Invasive } \\
\text { rhinosinusitis }\end{array}$ & Immunocompetent & $\begin{array}{l}\text { Loss } \\
\text { Follow-up }\end{array}$ \\
\hline Relloso et $\mathrm{al}^{5}$ & Man/55 & Sailing accident & $\begin{array}{l}\text { Cutaneous and } \\
\text { subcutaneous } \\
\text { mucormycosis }\end{array}$ & Immunocompetent & Resolution \\
\hline Tendolkar et al ${ }^{6}$ & Woman/44 & $\begin{array}{l}\text { History of } \\
\text { recurrent } \\
\text { sinusitis }\end{array}$ & $\begin{array}{l}\text { Invasive } \\
\text { rhinosinusitis }\end{array}$ & Immunocompetent & Resolution \\
\hline Rodríguez et al ${ }^{7}$ & Woman/29 & $\begin{array}{l}\text { Breast } \\
\text { augmentation } \\
\text { procedure }\end{array}$ & $\begin{array}{l}\text { Cutaneous and } \\
\text { subcutaneous } \\
\text { mucormycosis }\end{array}$ & Immunocompetent & Resolution \\
\hline Chander et al ${ }^{8}$ & $\begin{array}{l}2 \text { Men and } \\
3 \text { women/ } \\
37,60,31,40,55\end{array}$ & $\begin{array}{l}4 \text { intramuscular } \\
\text { injection, } \\
1 \text { medicated } \\
\text { tape application }\end{array}$ & $\begin{array}{l}\text { Necrotizing } \\
\text { fasciitis }\end{array}$ & $\begin{array}{l}4 \text { immunocompetent, } \\
1 \text { immunocompromised } \\
\text { (DM) }\end{array}$ & $\begin{array}{l}4 \text { resolution, } \\
1 \text { death } \\
\text { (immunocompetent) }\end{array}$ \\
\hline Present case & Boy, 1.4 & $\begin{array}{l}\text { Unknown } \\
\text { (Suspected } \\
\text { occult trauma) }\end{array}$ & $\begin{array}{l}\text { Cutaneous and } \\
\text { subcutaneous } \\
\text { mucormycosis }\end{array}$ & Immunocompetent & Resolution \\
\hline
\end{tabular}

is likely that the actual number of clinical cases might be underestimated due to difficulties in the identification of the species in addition to cases not reported. To identify S. erythrospora, culture on different media including potato dextrose agar, Czapek-Dox agar, malt extract agar, and Sabouraud dextrose with incubation at 25 to $37^{\circ} \mathrm{C}$ is recommended. Typical microscopic features of long sporangiophores, flask-shaped sporangia, and ellipsoid biconcave sporangiospores can be used to make the diagnosis. However, molecular identification based on DNA sequencing analysis of 3 loci (ITS, D1/D2, EF-1 $\alpha$ ) is useful for definitive diagnosis. $^{2}$

To the best of our knowledge, this is the first case report of pediatric periocular primary cutaneous and subcutaneous infection caused by S. erythrospora. In 2011, the first report of human infection caused by $S$. erythrospora occurred in a young man with invasive facial burns following blast trauma in Iraq. ${ }^{3}$ Since then there have been nine additional cases of $S$. eryhtrospora infection. All were adult patients and seven had either cutaneous/subcutaneous involvement or necrotizing fasciitis. Two patients had rhino-sinu-orbital diseases. All but one case was in immunocompetent individuals as in our case. From this point of view, it is possible that the immune status preferred by cutaneous and subcutaneous mucormycosis infected by this rare pathogen is immunocompetent status.

The mainstay of treatment should include adequate extensive surgical debridement along with appropriate antifungal regime and correction of any predisposing factors. Based on an in vitro susceptibility data, Saksenaea spp. had better response to posaconazole, itraconazole, and terbinafine (low minimum inhibitory concentrations: MICs) compared with echinocandins, voriconazole, and amphotericin B (high MICs)., 2,3 These profiles were different from antifungal susceptibility testing for Mucorales spp. previously reported. In our case, the patient was treated with intravenous liposomal amphotericin B and followed by oral itraconazole combined with aggressive surgical debridement. The patient responded well without long-term complications. The majority of cases in the literature have shown complete resolution. Only two fatal cases have been reported; one was the patient from the war injury, his autopsy revealed main causes of death were from fungal and bacterial sepsis with acute myocardial infarction. ${ }^{3}$ The second was one of the immunocompetent Indian cases who died from extensive tissue damage and fungal spread. ${ }^{8}$

In conclusion, primary cutaneous mucormycosis caused by $S$. erythrospora is rare but has been increasingly reported over the last decade. These cases can occur in immunocompetent individuals and we report, to the best of our knowledge, the first pediatric case. In our case, involvement of the medial canthus was initially diagnosed as dacryocystitis. The majority of reported cases have responded well to a regime of antifungal treatment and debridement.

\section{Conflict of Interest}

The authors have no financial or conflict of interest to disclose.

\section{References}

1 Ribes JA, Vanover-Sams CL, Baker DJ. Zygomycetes in human disease. Clin Microbiol Rev 2000;13(02):236-301

2 Alvarez E, Garcia-Hermoso D, Sutton DA, et al. Molecular phylogeny and proposal of two new species of the emerging pathogenic fungus Saksenaea. J Clin Microbiol 2010;48(12):4410-4416 
3 Hospenthal DR, Chung KK, Lairet K, et al. Saksenaea erythrospora infection following combat trauma. J Clin Microbiol 2011;49(10): 3707-3709

4 Chantharit P, Watcharananan S, Ornpaew P. P248 Invasive Saksenaea erythrospora rhino-orbital infection: the first case report in Thailand. Int J Antimicrob Agents 2013;42S2:S41-S159

5 Relloso S, Romano V, Landaburu MF, et al. Saksenaea erythrospora infection following a serious sailing accident. J Med Microbiol 2014;63(Pt 2):317-321

6 Tendolkar U, Joshi A, Koomen J, Bradoo R, Baveja S, Agrawal S. Rhinosinusitis caused by Saksenaea erythrospora in an immunocompetent patient in India: a first case report. JMM Case Rep 2015;xx:1-4. Doi: 10.1099/jmmcr.0.000044

7 Rodríguez JY, Rodríguez GJ, Morales-López SE, Cantillo CE, Le Pape P, Álvarez-Moreno CA. Saksenaea erythrospora infection after medical tourism for esthetic breast augmentation surgery. Int J Infect Dis 2016;49:107-110

8 Chander J, Singla N, Kaur M, et al. Saksenaea erythrospora, an emerging mucoralean fungus causing severe necrotizing skin and soft tissue infections - a study from a tertiary care hospital in north India. Infect Dis (Lond) 2017;49(03):170-177

9 Saksena SB. A new genus of the Mucorales. Mycologia 1953;45 (03):426-436

10 Ajello L, Dean DF, Irwin RS. The zygomycete Saksenaea vasiformis as a pathogen of humans with a critical review of the etiology of zygomycosis. Mycologia 1976;68(01):52-62

11 Kaushik R, Chander J, Gupta S, Sharma R, Punia RS. Fatal primary cutaneous zygomycosis caused by Saksenaea vasiformis: case report and review of literature. Surg Infect (Larchmt) 2012;13(02): 125-129 